\title{
Yellow-head virus of Penaeus monodon is an RNA virus
}

\author{
Chainarong Wongteerasupaya ${ }^{1}$, Siriporn Sriurairatana ${ }^{4}$, Joan E. Vickers ${ }^{5}$, \\ Anutara Akrajamorn ${ }^{6}$, Vichai Boonsaeng ${ }^{1}$, Sakol Panyim ${ }^{1}$, Anchalee Tassanakajon ${ }^{7}$, \\ Boonsirm Withyachumnarnkul $^{2}$, T. W. Flegel ${ }^{3, *}$
}

\author{
${ }^{1}$ Dept Biochemistry, ${ }^{2}$ Dept Anatomy, ${ }^{3}$ Dept Biotechnology, Fac. Science, Mahidol University, Rama VI Road. \\ Bangkok 10400, Thailand \\ ${ }^{4}$ Dept Pathology, Fac. Medicine, Ramathibodi Hospital, Mahidol University, Rama VI Road, Bangkok 10400, Thailand \\ ${ }^{5}$ Dept Microbiology, University of Queensland, Brisbane 4072, Australia \\ ${ }^{6}$ Charoen Pokphand Shrimp Culture Research Center, 82/2 Thonburi-Paktor Road, Klong Sunakhon, M 4 Bangtorat, \\ Amphur Muang, Samut Sakorn, Thailand \\ ${ }^{7}$ Dept Biochemistry, Fac. Science, Chulalongkorn University, Phya Thai Road, Bangkok 10400, Thailand
}

\begin{abstract}
Yellow-head virus (YHV) causes acute infections in Penaeus monodon that result in very high mortality. First reports of the virus suggested that the viral core consisted of DNA and that the virus should be classified as a granulosis-type baculovirus. However, 3 attempts at DNA extraction with high concentrations of purified virus (verified by transmission electron microscopy, TEM) gave only traces of DNA, which could not be visualized by ethidium bromide staining of agarose electrophoresis gels. Although selected recombinant clones derived from these pooled DNA traces did not hybridize with host shrimp DNA, they also failed to react with YHV-infected tissue by the in situ DNA hybridization technique. Furthermore, negatively stained virions of YHV viewed by TEM were atypical for baculoviruses and viral assembly is cytoplasmic. Therefore, renewed attempts to extract nucleic acid from purified YHV preparations focused on RNA rather than DNA. Hemolymph was collected aseptically by syringe from 200 artificlally YHV-infected, live shrimp in terminal stages of the disease. Purified virions were prepared by a program of centrifugation culminating in $22 \%$ to $45 \%$ Urografin gradient ultracentrifugation. A band at the 30-37\% interval of the gradient gave the cleanest preparation with the highest quantity of virions. By TEM these were enveloped, measured $150-170 \times 40-50 \mathrm{~nm}$ and were surrounded by a fringe of knob-like projections approximately $11 \mathrm{~nm}$ in length. Nucleic acid was extracted using guanidium thiocyanate and purified by $\mathrm{CsCl}$ gradient ultracentrifugation. High-molecular-weight nucleic acid was obtained which was degraded by RNase-A but not by DNase I. Based on morphology of negatively stained virions by TEM and on RNA content, YHV resembles rhabdoviruses or coronaviruses, rather than baculoviruses. This is an important discovery, since it necessitates cDNA preparation in the process to develop a nucleic-acid probe for YHV detection by the in situ or dot blot hybridization techniques.
\end{abstract}

KEY WORDS: Yellow-head virus - RNA $\cdot$ Penaeus monodon

\section{INTRODUCTION}

First reports of yellow-head disease in Penaeus monodon suggested that the causative virus (yellowhead virus, YHV) was a granulosis-like virus belong-

\footnotetext{
- Addressee for correspondence
}

ing to the family Baculoviridae (Boonyaratpalin et al. 1993, Chantanachookin et al. 1993). The tentative designation of YHV as a baculovirus in these publications was based on morphology of the enveloped virions as determined by transmission electron microscopy (TEM) of thin sections, on the mode of cytoplasmic assembly, and on a preliminary indication that the nucleic acid extracted from purified virions consisted 
of double-stranded DNA. There was also an additional report of intranuclear viral assembly in a time-lapse study of shrimp artificially infected with YHV by injection (Kasornchandra et al, 1993).

This study was carried out to isolate the nucleic acid from purified preparations of YHV and to substantiate the preliminary conclusion that it consisted of doublestranded DNA. Therefore, initial isolation protocols were specifically oriented towards the preparation of DNA. However, repeated failures to obtain expected quantities of DNA led to a change in the protocol, so that total nucleic acid could be extracted and analyzed. Results suggested that the original designation of YHV as a baculovirus was premature.

\section{MATERIALS AND METHODS}

Chemicals and reagents. All chemicals and reagents were purchased from Sigma Chemical Co. (St. Louis, MO, USA) unless otherwise indicated. Kits for digoxygenin labeling of DNA for use in dot blot hybridization and in situ hybridization assays were purchased from Boehringer Co. Ltd and assays were carried out as directed in the manual that accompanied the kits. DNA probes for monodon baculovirus (MBV) (Vickers et al. 1995) and systemic ectodermal and mesodermal baculovirus (SEMBV) (Wongteerasupaya et al. 1995) were prepared directly from clones on hand. A digoxygenin labeled DNA probe for infectious hematopoietic and hypodermal necrosis virus (IHHNV) was purchased from DiagXotics Inc. (27 Canon Rd, Wilton, CT, USA). RNase-A and DNase I were obtained from Sigma Chemical Co., while the restriction enzymes BamHI and EcoRI, and the molecular size marker $\lambda$-Hind III, were obtained from BRL (Bethesda Research Laboratories, Gaithersburg, MD, USA), and T4 DNA ligase was obtained from New England Biolab.

Virus purification. Several different isolation protocols were tested for the preparation of purified virus particles. For each protocol, approximately 200 juvenile shrimp of $20 \mathrm{~g}$ average weight were injected with a serially transferred viral preparation, as previously described (Wongteerasupaya et al. 1995). In each protocol, gills, lymphoid organs or hemolymph was removed from these shrimp when they had become moribund. In some protocols, gills and lymphoid organs were removed and processed immediately or frozen in liquid nitrogen and processed later. In other protocols, whole shrimp were quick frozen in liquid nitrogen and gills or lymphoid organs were removed for later processing. Fresh or thawed tissues were homogenized in twice their volume of lobster hemolymph medium (LHM) (Wongteerasupaya et al. 1995) followed by centrifugation on a Sorvall Super- speed RC2-B centrifuge (SS-34 rotor) at $480 \times g$ and $4^{\circ} \mathrm{C}$ for $30 \mathrm{~min}$ to remove cellular debris. Hemolymph was removed by syringe from the sinuses at the base of the walking legs and mixed with twice the volume of LHM on ice before immediate centrifugation as above, or it was frozen in liquid nitrogen and centrifuged later, after thawing.

After centrifugation, pellets were discarded and the supernatant fluids were further centrifuged at $100000 \times$ $g$ at $4^{\circ} \mathrm{C}$ for $1 \mathrm{~h}$ on a Beckman ultracentrifuge (Ti 70.1 rotor). The supernatant fraction was then discarded and the pellet was gently resuspended overnight in $1 \mathrm{ml}$ of LHM at $4^{\circ} \mathrm{C}$. This suspension was layered onto the top of a continuous gradient of $22 \%$ to $45 \%$ Urografin and ultracentrifuged at $100000 \times g$ on a Beckman ultracen-

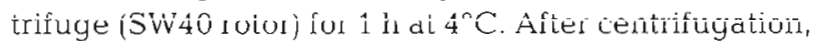
viral bands were visualized by top illumination and were removed using a Pasteur pipette. A drop of each fraction was used for negative staining and visualization with the transmission electron microscope (see below). The remainder of the removed bands were diluted with NTE buffer $(0.2 \mathrm{M} \mathrm{NaCl}, 0.02 \mathrm{M}$ Tris- $\mathrm{HCl}$ and $0.02 \mathrm{M}$ EDTA) at $\mathrm{pH} 7.4$ to give a final volume of $12 \mathrm{ml}$ before centrifugation at $100000 \times g$ for $1 \mathrm{~h}$ as above. The pellet (purified virions) was then resuspended in $50 \mu \mathrm{l}$ of TE buffer (10 mM Tris- $\mathrm{HCl}$ and $1 \mathrm{mM}$ EDTA) at $\mathrm{pH} 7.4$ and stored at $-70^{\circ} \mathrm{C}$ until used.

For TEM, negatively stained samples were prepared on formvar coated copper grids as follows. A small drop of sample diluted 10 -fold was placed on the grid and left to stand for 20 min before excess fluid was withdrawn with a piece of tissue paper held to the side of the grid. Then a drop of $0.5 \%$ sodium phosphotungstate (Sigma Chemical Co.) was placed on the grid and left for 2 min before the excess was removed as above. After air drying, the grids were examined with a Hitachi HU-12A transmission electron microscope.

Nucleic acid isolation and characterization. Initial attempts at nucleic acid extraction specifically targeted DNA and they have been described elsewhere (Wongteerasupaya et al. 1995), along with methods for gel electrophoresis and DNA visualization. These procedures included RNase-A treatment that would have destroyed any RNA present in the samples. Later attempts at nucleic acid extraction were modified to obtain total nucleic acid. Specifically, purified virion preparations $(50 \mu l)$ were mixed with $100 \mu l$ guanidium thiocyanate lysis solution or GuSCN (containing $4 \mathrm{M}$ guanidium thiocyanate, $25 \mathrm{mM}$ sodium citrate, $0.5 \%$ sarcosyl and $0.1 \mathrm{M} 2$-mercaptoethanol at pH 7.0) and homogenized at high speed for $1 \mathrm{~min}$ in a tissue grinder (RNase-free) This GuSCN lysate was then overlayered onto $100 \mu \mathrm{l}$ of $5.7 \mathrm{M} \mathrm{CsCl}$ and centrifuged at $230000 \times g$ for $2 \mathrm{~h}$ at $20^{\circ} \mathrm{C}$ on a Beckman TL-100 ultracentrifuge. The overlaid fraction, $\mathrm{CsCl}$ fraction and pellet were then separated. The 
pellet (RNA) and CsCl fractions were then processed separately as follows. The pellet (RNA) was dissolved in $100 \mu$ diethyl pyrocarbonate (DEPC)-treated water and precipitated by addition of $10 \mu \mathrm{l}$ of $2.5 \mathrm{M}$ ammonium acetate, $\mathrm{pH} 5.0$, and $200 \mu \mathrm{l}$ ice-cold ethanol, followed by storage at $-20^{\circ} \mathrm{C}$ for $2 \mathrm{~h}$. The RNA was pelleted by centrifugation at $3500 \times g$ for $15 \mathrm{~min}$ at $4^{\circ} \mathrm{C}$ (Beckman TL 100) and then it was washed twice with ice-cold ethanol to remove residual salt. The pellet was then resuspended in $20 \mu l$ of DEPC-treated water and stored at $-70^{\circ} \mathrm{C}$ until used. By contrast, the total $\mathrm{CsCl}$ fraction (no bands visible) was mixed with $10 \mu \mathrm{l}$ of $2.5 \mathrm{M}$ ammonium acetate, pH 5.0, and $200 \mu \mathrm{l}$ ice-cold $70 \%$ ethanol, followed by storage at $-20^{\circ} \mathrm{C}$ for $2 \mathrm{~h}$. Thereafter, it was treated in the same manner as the pellet fraction to precipitate, resuspend and store any nucleic acid present.

DNA cloning and in situ hybridization. Pooled DNA extracts from preliminary DNA extractions (no visible bands on agarose gels by UV detection) were digested with BamHI and EcoRI to obtain DNA fragments for ligation with Bluescribe vector using T4 ligase. The resulting plasmids were used to transform competent cells of Escherichia coli JM 107. Recombinant clones (nos. 9, 10 and 12) that gave negative hybridization with shrimp DNA and SEMBV DNA were selected and digested with the restriction endonucleases BamHI and EcoRI. This yielded DNA fragments that were electrophoresed and eluted from low melting agarose gel using agarase (Boehringer Mannheim GmbH). They were then labeled with digoxygenin (Boehringer Mannheim Genius System) using the random prime method as directed in the kit instructions.

YHV-infected and non-infected gill tissues (verified by coupled TEM specimens) were processed by normal histological techniques (Bell \& Lightner 1988). Sections were prepared on Fisher positive microscope slides (Fisher Scientific) followed by processing for in situ DNA hybridization according to the Boehringer manual. Tissues were treated with proteinase-K (20 to $30 \mu \mathrm{l}$ of a $100 \mu \mathrm{g} \mathrm{ml} \mathrm{m}^{-1}$ solution) for $15 \mathrm{~min}$ at $37^{\circ} \mathrm{C}$, washed, and heated at $95^{\circ} \mathrm{C}$ for $6 \mathrm{~min}$ before hybridization with the DNA probes described above.

Dot blot hybridization. Dot blot hybridizations were carried out using digoxygenin-labeled DNA (Boehringer Mannheim Genius System) according to the Boehringer manual.

\section{RESULTS}

\section{Virus purification}

Of all the protocols attempted for viral isolation and purification, the best results, in terms of high numbers of uncontaminated virions, were obtained using fresh hemolymph preparations. Since these required no homogenization step, they were the gentlest and most rapid to carry out. Even freezing and thawing of hemolymph caused damage to the virions (see below). Homogenized tissues, fresh or thawed, gave less satisfactory results than hemolymph, and gill preparations were particularly troublesome since homogenates quickly melanized unless antioxidants, such as ascorbic acid, were added.

Ultracentrifugation of crude virus precipitate from fresh hemolymph preparations on Urografin gradients (Fig. 1) gave a strong band at the 30-37\% interval. By TEM, this band gave the highest quantity of undamaged virions and the lowest quantity of contaminating material. By contrast, virions prepared from frozen hemolymph in a similar manner showed evidence of extensive virion damage (Fig, 2a). Intact virions (Fig. 2b) were enveloped, measured 150-170 $\times$ $40-50 \mathrm{~nm}$ and were surrounded by a fringe of knoblike projections approximately $11 \mathrm{~nm}$ in length. Some short virions associated in pairs appeared to have arisen by fragmentation of longer virions (Fig. 2b).

\section{Nucleic acid extraction and characterization}

Initial nucleic acid extractions with concentrated viral preparations were carried out specifically for DNA and included RNase treatment in the protocol.

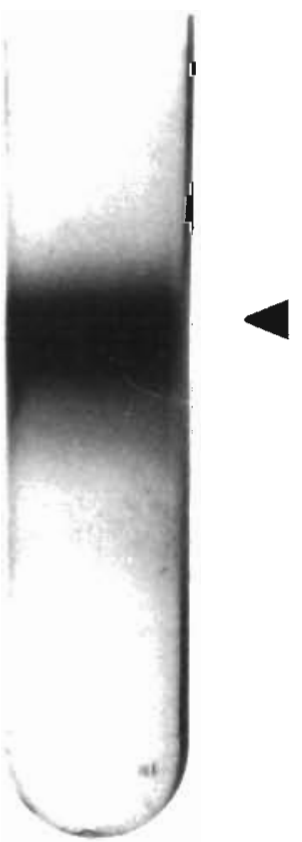

Fig. 1. Photograph of a top-lighted Urografin gradient tube prepared using crude virus from a fresh Penaeus monodon hemolymph preparation. A strong band of virions can be seen at the $30-37 \%$ interval 


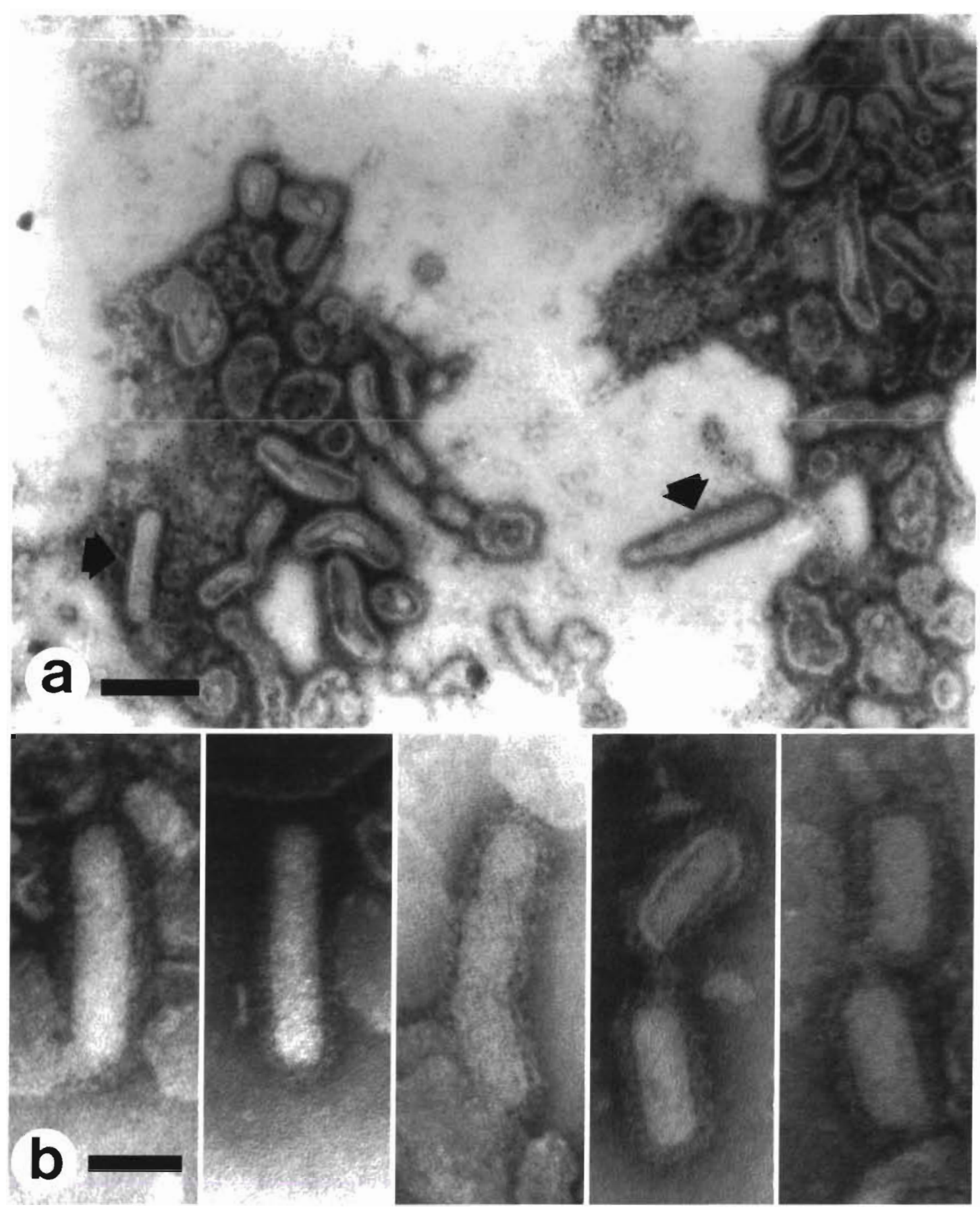

Fig. 2. Transmission electron micrograph of negatively stained virions from YHV-infected Penaeus monodon. (a) Low magnification of virions prepared from frozen hemolymph. Two virions (arrows) are relatively intact, but most others are obviously damaged. Scale bar $=150 \mathrm{~nm}$. (b) High magnification of intact virions showing a fringe-like border of knobs. The 2 pairs of small virions on the right appear to be linked. Scale bar $=50 \mathrm{~nm}$

However, DNA bands could not be detected by agarose gel electrophoresis of these extracts. In spite of this, the traces of DNA from 3 such extractions were pooled and cloned into Bluescribe vector after diges- tion with BamHI and EcoRI. From the colonies with inserts, 3 clones (nos. 9, 10 and 12) were selected because they hybridized with the original DNA pool, but did not hybridize with shrimp DNA or with DNA 
Fig. 3. Photograph of electrophoresis gels of purified nucleic acid fractions from YHV after $\mathrm{CsCl}$ gradient centrifugation. (a) Lanes: (1) $\lambda$-Hind III marker, (2) $\lambda$-Hind III marker pre-treated with DNase I, (3) CsCl fraction pre-treated with DNase I, (4) pellet fraction pre-treated with DNase $\mathrm{I}_{1}(5)$ untreated $\mathrm{CsCl}$ fraction, (6) untreated pellet fraction, (7) RNA reference standard. (b) The same gel as in panel (a), after treatment of the whole gel with RNase-A. Note that a faint band of DNA is present in lane 5 of both figures
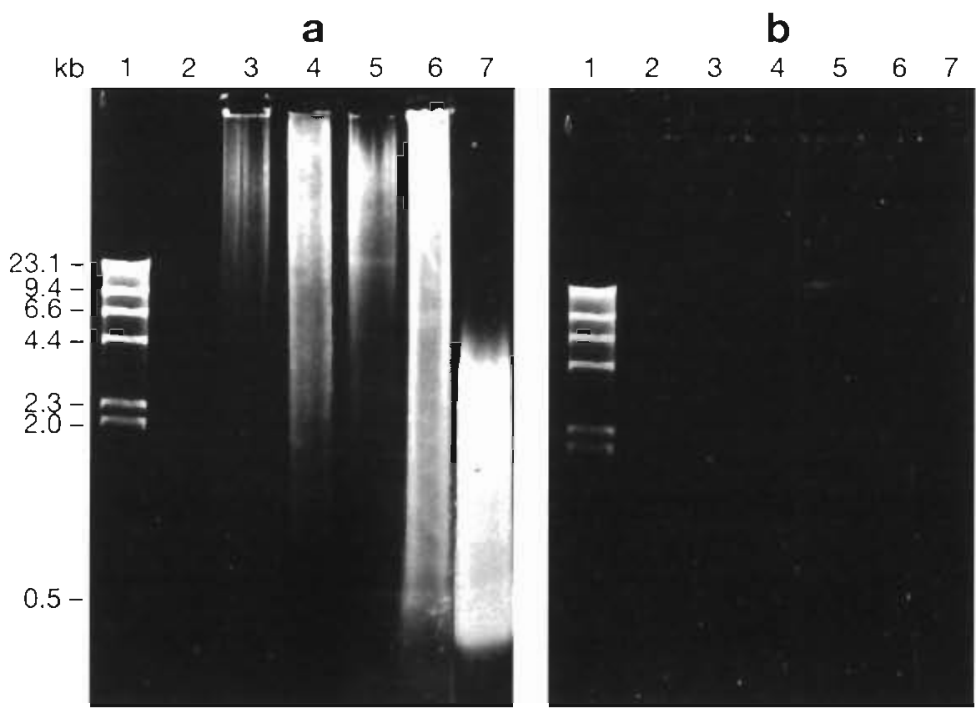

from SEMBV. However, these clones also gave negative hybridization results when tested by in situ hybridization with YHV-infected gill tissue. Because of these negative results and because purified virions were atypical of baculoviruses in negatively stained transmission electron micrographs, additional extraction attempts were made in a manner that preserved total nucleic acid, including RNA

For the extractions designed to preserve RNA, guanidium thiocyanate was used. The total nucleic acid was then purified by $\mathrm{CsCl}$ gradient ultracentrifugation. The pellet fraction and $\mathrm{CsCl}$ fraction nucleic acid were subjected to $0.75 \%$ agarose gel electrophoresis with and without prior treatment by DNase I (Fig. 3a). The gel also contained a molecular weight marker ( $\lambda$-Hind III with and without DNase I treatment) and control RNA. The whole gel was subsequently treated with RNase-A (Fig. 3 b). The results by UV visualization showed that the nucleic acid in the CsCl fraction consisted of RNA with a trace of DNA and that the pellet fraction consisted of RNA only. Thus the total viral extract contained a mixture of DNA and RNA, but the comparative intensities indicated that the RNA was overwhelmingly dominant.

The DNA fraction obtained from the total nucleic acid extraction process (lane 5 in Fig. 3a, b) failed to bind with DNA from the host shrimp, SEMBV and IHHNV in dot-blot hybridization assays. However, it also failed to give a positive reaction in in situ DNA hybridization tests with gill tissue from shrimp specimens confirmed to be infected with YHV by TEM of thin sections. This was similar to the results obtained with the original pooled DNA extractions which gave no visible band in agarose gels (see above). The source of these DNA fractions is still unknown

\section{DISCUSSION}

The size and morphology of the negatively stained virions reported here correspond to those in TEM micrographs of thin tissue sections in the original descriptions of YHV (Boonyaratpalin et al. 1993, Chantanachookin et al. 1993). However, the negatively stained preparations revealed a fringe of knob-like projections that were not described in the original reports. Cytoplasmically assembled, rod-shaped, enveloped virions with fringe-like borders have been reported for the single-stranded RNA virus families Coronaviridae (plus-strand RNA), Rhabdoviridae (minus-strand RNA) and Paramyxoviridae (minusstrand RNA) (Ishihama \& Barbier 1994). From these families, rhabdovirus-like or paramyxovirus-like particles have been reported in crustaceans (Bonami \& Lightner 1991), but coronaviruses have not. In TEM of thin tissue sections, rhabdolike virus-A of crabs has some similarities to YHV in terms of tissue specificity, site of virion assembly, virion size, virion shape and the production of long filamentous forms (Bonami \& Lightner 1991). However, there are also distinctive differences in that YHV nucleic acid cores appear to issue from the nucleus, acquire nucleocapsids in the cytoplasm, become enveloped by passing through the endoplasmic reticulum, and then fragment into smaller, mature virions in vesicles (Chantanachookin et al. 1993).

There are other reports (Lu et al. 1991, Lu \& Loh 1992) of a virus isolated from Penaeus stylirostris and $P$. vannamei and cultured in a fish cell line where typical bullet-shaped rhabdovirus articles $(65-77 \times 115-$ $138 \mathrm{~nm}$ ) were produced. However, Lu \& Loh (1992) state that little is known about the disease-causing 
capacity of this virus in penaeid shrimp. They reported that experimental infections in $P$. stylirostris caused cytoplasmic alterations in the lymphoid organ but that there were no overt signs of disease. Since no electron micrographs have been published showing this virus replicating in shrimp tissues, it is difficult to assess how it relates to the RNA virus reported here.

In concert with the negative staining results, this investigation has shown that RNA can be extracted from YHV in quantities commensurate with the numbers of virions in purified extracts. Together, the morphological and biochemical data strongly suggest that YHV is an RNA virus rather than a DNA virus, as was previously suggested (Boonyaratpalin et al. 1993, Chantanachookin et al. 1993). Which of the 3 known families of rod-shaped viruses is appiopirate for ril riv would depend first upon whether it contained plusstrand RNA (Coronaviridae) or minus-strand RNA (Rhabdoviridae and Paramyxoviridae) (Ishihama \& Barbier 1994). If it were found to contain doublestranded RNA or ambisense RNA, it would represent a completely new type of rod-shaped virus.

Acknowledgements. The authors thank the National Center for Genetic Engineering and Biotechnology of Thailand for funds to carry out this work. They also thank Aquastar Co. Ltd for supporting Dr Vickers to come to Thailand to join in this work.

\section{LITERATURE CITED}

Bell TA, Lightner DV (1988) A handbook of normal penaeid shrimp histology. World Aquaculture Society, Baton Rouge

Responsible Subject Editor: J. E. Stewart, Dartmouth, N.S., Canada
Bonami JR, Lightner DV (1991) Unclassified viruses of Crus tacea. In: Adams JR, Bonami JR (eds) Atlas of invertebrate viruses, Chap 24. CRC Press, Boca Raton, p 597-622

Boonyaratpalin S, Supamataya K, Kasornchandra J, Direkbusarakom S, Ekpanithanpong U, Chantanachookhin C (1993) Non-occluded baculo-like virus the causative agent of yellow-head disease in the black tiger shrimp Penaeus monodon. Fish Pathol 28:103-109

Chantanachookin C, Boonyaratpalin S, Kasornchandra J, Direkbusarakom S, Ekpanithanpong U, Supamataya K, Sriurairatana S, Flegel TW (1993) Histology and ultrastructure reveal a new granulosis-like virus in Penaeus monodon affected by yellow-head disease. Dis aquat Org 17:145-157

Ishihama A, Barbier P (1994) Molecular anatomy of viral RNA-directed RNA polymerases. Brief review. Arch Virol 134:235-258

Kasornchandra J, Supamattaya K, Boonyaratpalin S (1993) Electron microscopic observations on the replication of yellow-head baculovirus in the lymphoid organ of Penaeus monodon. Asian Shrimp News 15:2-3

Lu Y, Loh PC (1992) Some biological properties of a rhabdovirus isolated from penaeid shrimp. Arch Virol 127 $339-343$

Lu Y, Nadala ECB, Brock JA, Loh PC (1991) A new virus isolate from infectious hypodermal and hematopoietic necrosis virus (IHHNV)-infected penaeid shrimps. J virol Methods 31:189-196

Vickers JE, Bonami JR, Flegel TW, Ingham AB, Kidd SP, Lester RJG, Lightner DV, Mari J, Pemberton JM, Spradbrow PB, Wang JH, Wong FYK, Young PR (1995) A gene probe for monodon baculovirus. In: Shariff $M$, Subasinghe RP, Arthur JR (eds) Diseases in Asian aquaculture Il. Fish Health Section, Asian Fisheries Society, Manila (in press)

Wongteerasupaya C, Vickers JE, Sriurairatana S, Nash GL, Akarajamorn A, Boonsaeng V, Panyim S, Tassanakajon A, Withyachumnarnkul B. Flegel TW (1995) A non-occluded, systemic baculovirus that occurs in cells of ectodermal and mesodermal origin and causes high mortality in the black tiger prawn Penaeus monodon. Dis aquat Org 21:69-77

Manuscript first received: September 19, 1994 Revised version accepted: December 29, 1994 